\title{
Allozymic variability in beechwoods (Fagus sylvatica L.) over central Europe: spatial differentiation among and within populations
}

\author{
B. Comps, \\ B. Thiébaut, $\dagger$ \\ L. Paule, $\neq$ \\ D. Merzeau* and \\ J. Letouzey*
}

* Université de Bordeaux I, Département de Biologie
végétale-Ecologie génétique. Avenue des Facultés,
F-33405 Talence, France.
† C.N.R.S., Centre L. Emberger, BP 5051, F-34033
Montpellier, France et Institut de Botanique, 163 rue
Auguste Broussonnet, F-34000 Montpellier, France.
† Faculty of Forestry, University of Forestry and
Wood Processing, CS-96053 Zvolen, Czechoslovakia.

One hundred and forty beech stands located in central and Mediterranean Europe have been analysed using six enzymatic loci ( $P X-1, P X-2, G O T-1, I D H-1, M D H-1$ and $P G I-1)$. They were investigated on allelic and genotypic levels with the aim of estimating the intra- and inter-population components of their genetic differentiation. Four loci $(P X-1, P X-2, M D H-1$ and $I D H-1)$ were found rather polymorphic whereas the remaining two (GOT-1 and $P G I-1)$ showed a lower degree of polymorphism. Significant association of climate and allelic diversity was found for two loci $(P X-1$ and $P X-2)$. Differences between the continental and the Mediterranean regions are sometimes significant at the allelic level, especially for $G O T-1, M D H-1$ and $I D H-1$ loci. In all cases, the inter-population component of the diversity is much lower than the intra-population one but it is higher in the Mediterranean region except in the PGI-1 locus.

\section{INTRODUCTION}

The genetic structure of beech stands depends on selection and the mating system, in addition to gene flows and genetic drift; these factors induce an inter- and an intra-population genetic differentiation over space and time (Kim 1979, 1980; MüllerStarck, 1985; Gregorius et al., 1986; Cuguen, 1986; Cuguen et al., 1988).

Beech is considered as a climax species in most part of Europe where it grows in very different environments. Particularly in the southern part of its area, near the Mediterranean Sea, beech stands develop in very contrasted climates: Mediterranean or continental, and plain or mountain climates (Misic, 1957; Comps, 1972; Thiébaut, 1984). This environmental diversity favours the genetic differentiation of beechwoods by selection and genetic isolation due to phenological differences (Thiébaut et al., 1982; Felber and Thiébaut, 1982, 1984; Thiébaut, 1984; N'Tsiba, 1984; Barrière et al., 1985; Comps et al., 1987).

Beech is a monoecious species which does not reproduce until it is at least 40 or 50 years old.
The species is anemophilous and mostly allogamic (Schaffalitzky de Muckadell, 1955). In natural conditions (wind-pollination), the beech outcrossing rate varies between 0.90 and 1.00 , with 0.95 on average (Merzeau et al., in preparation). This average is higher than the one $(0.87)$ estimated in artificial conditions (controlled-pollination) by Nielsen and Schaffalitzky de Muckadell (1954). In addition to self-fertilization, another component of inbreeding can intervene within beech populations. Gene flows are generally limited in the optimal range of the Beech because of the high density of beechwoods, thus reproduction likely occurs between closely spaced individuals and genetic structures could best be described by the "isolation by distance model" of Wright (1943, 1946) (Cuguen, 1986; Cuguen et al., 1988). This model induces an increasing relatedness between individuals among and within populations, therefore a genetic differentiation; it also contributes to this differentiation of beech populations by genetic drift. However, gene flows vary according to the age and the physiognomical aspects of the population (Thiébaut et al., 1986). 
The history of the Beech after the last glacial period is well known. Today's stands apparently spread out from an important source located in the Balkans and from several secondary sources in southwestern Europe (Oldfield, 1960; Paquereau, 1965, 1970, 1974; Beug, 1967; Sercelj, 1970; Jalut, 1974; Jalut et al., 1975; Triat-Laval, 1978; Pons, 1983). One beech generation is at least 60 to 100 years. Therefore, recently established beech stands have passed through few generations at their present sites. It seems that Beech has reached the different countries of its present range at various periods: southern countries (close to the Mediterranean Sea) since 5000 or $4000 \mathrm{BP}$ and central European ones only since 3000 or 2500 BP (Vernet 1981). Thus, a higher number of generations has passed in the south than in the north.

Genetic differentiation among and within beech stands seems to be much higher towards the south where climatic conditions are more heterogeneous, and the populations are older and their sources more numerous.

The allozyme variation of beech stands across Europe has already been analysed using only three loci. Allelic frequencies vary according to climatic changes for two peroxidase loci $(P X-1$ and $P X-2)$, particularly in the southern countries.* This fact may be partly interpreted as an effect of selection. For another locus (glutamate oxaloacetate transaminase, $G O T$-1), allelic frequencies do not vary as a function of environmental conditions but, are related to the history of the populations (Thiébaut et al., 1982; Felber and Thiébaut, 1982, 1984; Thiébaut, 1984; N'Tsiba, 1984; Barrière et al., Cuguen et al., 1985; Comps et al., 1987). Other authors have studied the effects of selection between several generations (Kim, 1979, 1980; Gregorius et al., 1986) or as a consequence of pollution (Müller-Starck, 1985).

The aim of this paper is to investigate the genetic differentiation of beech stands in central and southern Europe.

\section{MATERIAL AND METHODS}

\section{Sampling}

The 140 sampled beech stands are distributed over a wide geographical range from Poland in the north

\footnotetext{
* Conventionally, we will use the term "regions" when talking about the northern and the southern parts of the studied area, respectively characterized by continental and Mediterranean climates; "country" will be used in its proper meaning but also to name administrative subdivisions as Corsica, Serbia and Croatia.
}

as far as Italy and Corsica in the south; it includes Rumania and Bulgaria towards the east. The number of stands sampled in each of these two last countries and in Serbia is rather low, so we pooled them considering their geographical and environmental similarity. In each beech stand, plant material (buds and twigs) was sampled from about 50 non-adjacent trees chosen at random over a 3-4 ha area and in as homogeneous an environment as possible.

Sampling was carried out according to the heterogeneity of environmental factors (fig. 1, table 1): climate, topographic location, aspect, soil $p \mathrm{H}$. Only climate variation could be more or less connected with genetic structure of beechwoods; so, we are going to discuss only this.

Climate varies a great deal according to latitude and altitude.

From the north towards the south, the various types of climate encountered are continental in Poland, Czechoslovakia, Rumania, Bulgaria and Serbia, both continental and Mediterranean in Croatia, only Mediterranean in Italy and also in Corsica where climate is, however, more insular. Thus, we could distinguish two climatic regions, continental and Mediterranean.

Climate varies as a function of altitude; the altitudinal range of investigated beechwoods differs from one country to another: $100-500 \mathrm{~m}$ in Poland, 390-1400 $\mathrm{m}$ in Czechoslovakia, 600$1200 \mathrm{~m}$ in Bulgaria, Rumania and Serbia, 260$1645 \mathrm{~m}$ in Croatia, $800-1450 \mathrm{~m}$ in Italy and 1100 $1450 \mathrm{~m}$ in Corsica.

Taking into account both latitude and altitude, the climate variety of sampling areas increases firstly from the north in Poland towards the south as far as Croatia; then it decreases from Croatia towards Italy and Corsica.

\section{Biochemical analysis}

Extraction from buds and cortical tissues of twigs, electrophoresis and staining were performed using the techniques described by Thiébaut et al., (1982) and Merzeau et al. (In press). The genetic variation of beech populations was studied using six polymorphous loci: $P X-1, P X-2$ (peroxidases), GOT-1 (glutamate oxaloacetate transaminase), $P G I-1$ (phosphoglucose isomerase), MDH-1 (malate dehydrogenase) and $I D H-1$ (isocitrate dehydrogenase). The first four loci have already been used in West European beech studies (Cuguen et al., 1985; Comps et al., 1987), the latter two are being used for the first time. Three loci ( $P X-1$, $G O T-1$ and $M D H-1$ possess two codominant alleles while the remainder $(P X-2, I D H-1$ and 


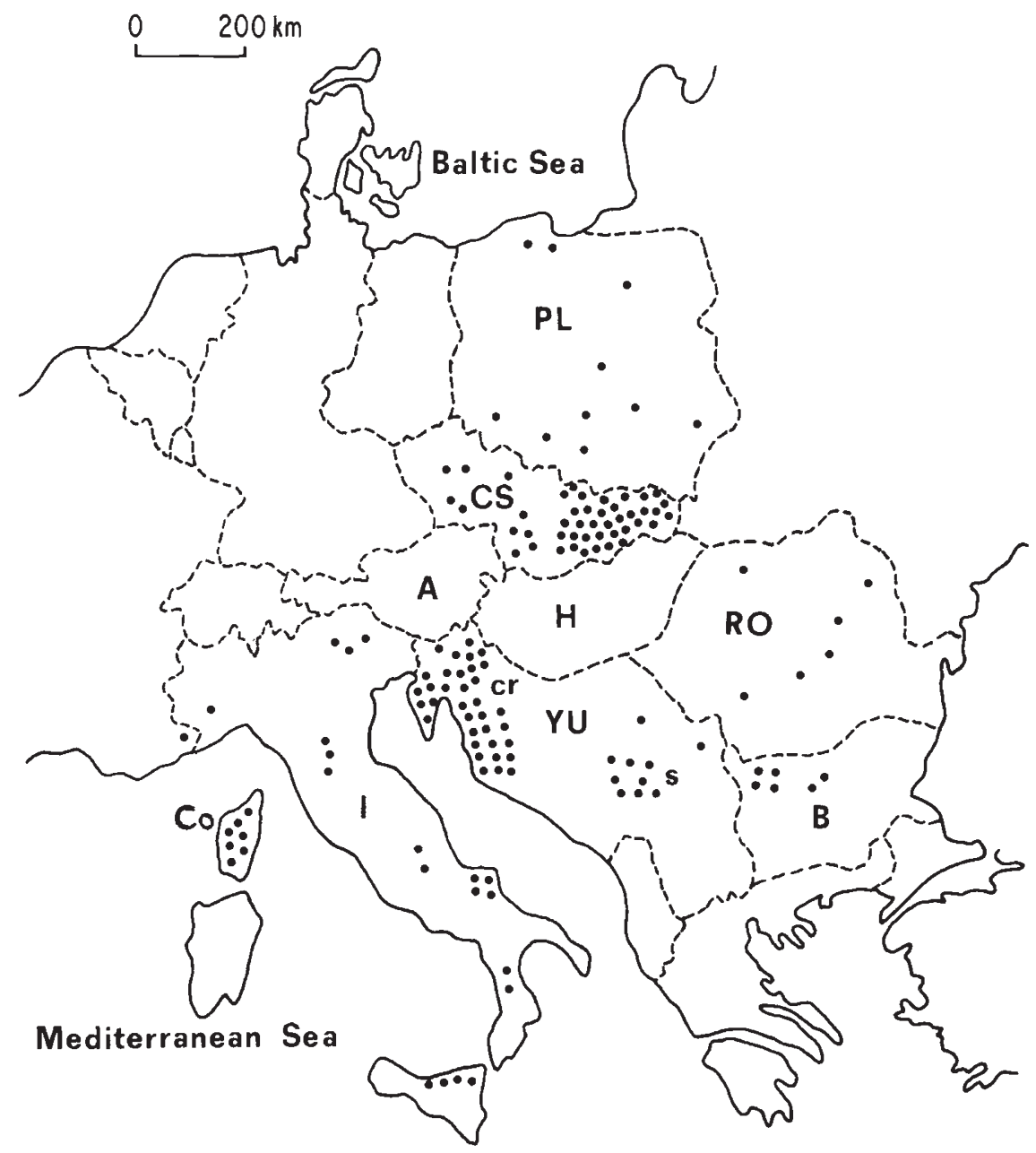

Figure 1 Location of beechwoods studied: PL, Poland; CS, Czechoslovakia; A, Austria; H, Hungary; Ro, Rumania; I, Italy; Yu, Yugoslavia; cr. Croatia; s, Serbia; B, Bulgaria; Co, Corsica.

PGI-1) possess three codominant alleles (Thiébaut et al., 1982; Merzeau et al. In press).

\section{Mathematical analyses}

The total genetic differentiation among all the beechwoods studied is partitioned into inter- and intrapopulation components. They were estimated using two methods based on allelic and genotypic criterions.

\section{Allelic differentiation}

We used a nested anova with arcsine transformation to test both the inter-region and intercountry variabilities of allelic frequencies. Then, the studied countries were compared in pairs using Tukey-Kramer's test (Dunnet, 1980). However, even if this test is well adapted to multiple comparisons among pairs in case of unequal sample sizes, it is very conservative and sometimes hides differences which nevertheless seem to tally with biological reality. So that we also carried out a single classification anova in order to compare both series of results, even if we have increased the risk of a type 1 error.

The total gene diversity $\left(H_{\mathrm{T}}\right)$ was estimated using Nei's procedure $(1973,1977){ }^{*} H_{\mathrm{T}}=1-\sum p_{i}$ where $\bar{p}_{i}$ is the mean frequency of the $i$ th allele, weighted by the sample size. $H_{\mathrm{T}}$ is partitioned as $H_{\mathrm{T}}=H_{\mathrm{S}}+D_{\mathrm{ST}}$ where $H_{\mathrm{S}}$ and $D_{\mathrm{ST}}$ are the weighted average gene diversity within and among populations, respectively.

* As recommended by Nei (1973), we will use the word "gene diversity" instead of heterozygosity. 
Table 1 Beech stand $(N)$ and tree $(n)$ numbers studied according to the locus and the territory

\begin{tabular}{|c|c|c|c|c|c|c|c|}
\hline $\begin{array}{l}\text { Loci } \\
\text { No. of alleles }\end{array}$ & & $\begin{array}{l}P X-1 \\
2\end{array}$ & $\begin{array}{l}P X-2 \\
3\end{array}$ & $\begin{array}{l}\text { GOT-1 } \\
2\end{array}$ & $\begin{array}{l}M D H-1 \\
2\end{array}$ & $\begin{array}{l}I D H-1 \\
3\end{array}$ & $\begin{array}{l}P G I-1 \\
3\end{array}$ \\
\hline \multirow[t]{2}{*}{ Whole area } & $N$ & 143 & 143 & 143 & 121 & 99 & 114 \\
\hline & $n$ & 6795 & 7041 & 7289 & 5611 & 4646 & 5640 \\
\hline \multirow[t]{2}{*}{ Continental region } & $N$ & 97 & 97 & 97 & 85 & 64 & 79 \\
\hline & $n$ & 5200 & 4287 & 3899 & 3193 & 2313 & 4443 \\
\hline \multirow{2}{*}{ Mediterranean region } & $N$ & 46 & 46 & 46 & 36 & 35 & 35 \\
\hline & $n$ & 1595 & 2754 & 3390 & 2418 & 2333 & 1197 \\
\hline \multirow[t]{2}{*}{ Poland } & $N$ & 10 & 10 & 10 & 6 & 6 & - \\
\hline & $n$ & 371 & 476 & 452 & 261 & 264 & - \\
\hline \multirow[t]{2}{*}{ Czechoslovakia } & $N$ & 46 & 46 & 46 & 44 & 30 & 43 \\
\hline & $n$ & 2239 & 2448 & 2671 & 2114 & 1530 & 2324 \\
\hline \multirow{2}{*}{$B+R+S$} & $N$ & 22 & 22 & 21 & 16 & 11 & 15 \\
\hline & $n$ & 1052 & 985 & 937 & 576 & 321 & 596 \\
\hline \multirow[t]{2}{*}{ Croatia } & $N$ & 35 & 35 & 35 & 35 & 33 & 35 \\
\hline & $n$ & 1896 & 1908 & 1896 & 1829 & 1643 & 1904 \\
\hline \multirow[t]{2}{*}{ Italy } & $N$ & 21 & 21 & 22 & 11 & 10 & 10 \\
\hline & $n$ & 953 & 892 & 963 & 483 & 504 & 420 \\
\hline \multirow[t]{2}{*}{ Corsica } & $N$ & 9 & 9 & 9 & 9 & 9 & 9 \\
\hline & $n$ & 274 & 332 & 370 & 348 & 384 & 396 \\
\hline
\end{tabular}

B + R+S: Bulgaria + Rumania + Serbia.

Gene diversities were compared using only a non-parametric test because their distribution law is unknown. We tried to carry out multiple comparisons among pairs of countries, based on unequal sample sizer, using Noether's method (1976) which takes into account the experimentwise error rate (Sokal and Rohlf, 1981); but we sometimes found inconsistent results probably due to type II errors, the risk of which is unknown. So for all comparisons among pairs we used the Mann-Whitney test, even if we have slightly (low number of comparisons) increased the risk of a type I error.

Finally, we carried out a discriminant analysis (Escouffier et al., 1988) including all loci together (except $P G I-1)$ to compare (1) the two climatic regions, (2) the different countries. Only one allele was taken into account for each diallelic locus and only two for each triallelic locus. The axis number equals the number of classes compared minus one, thus when comparing continental and Mediterranean regions, there is only one axis (fig. 2).

\section{Genotypic differentiation}

Genotypic structures are often analysed using $F$ statistics (Wright, 1965). A relationship can occur between $F$-statistic values and gene diversity, especially when the latter is very low (Wright, 1951 and 1978; Cuguen, 1986). One of the loci (PGI-1 generally reaches low diversities, thus it often transgresses the assumption of independence from
$F$-values. $F_{\mathrm{IT}}$ is an estimation of the total genotypic differentiation and as for gene diversity, it is partitioned into intra- $\left(F_{\mathrm{IS}}\right)$ and inter- $\left(F_{\mathrm{ST}}\right)$ population components.

Estimates of the $F$-statistics were computed according to the method of Weir and Cockerham (1984). They are weighted by the sample size, the variance and the number of stands studied. For each $F$-statistic, a variance was estimated using a jackknife procedure allowing us to determine whether each $F$-value is significantly different from 0 and to test deviations between two regions.

\section{RESULTS}

\section{Allelic differentiation}

\section{Heterogeneity between regions and among countries within regions}

Allelic frequencies differ significantly among countries, whatever the locus may be but not between the two climatic regions, except for $M D H$-1 (table 2 ). In the whole area, gene diversities are rather high for four loci, not for GOT-1 $\left(H_{\mathrm{T}}=0.175\right)$ and for $P G I-1\left(H_{\mathrm{T}}=0.045\right)$ (table 3$)$. The intrapopulation component is always higher than 90 per cent. The gene diversity is significantly higher in the Mediterranean stands only for GOT-1 locus $(P<$ $0.001)$ and significantly lower for $I D H-1$ and $M D H-1$ loci $(P<0 \cdot 001)$. This confirms results concerning the allelic frequencies of $M D H-1$ 


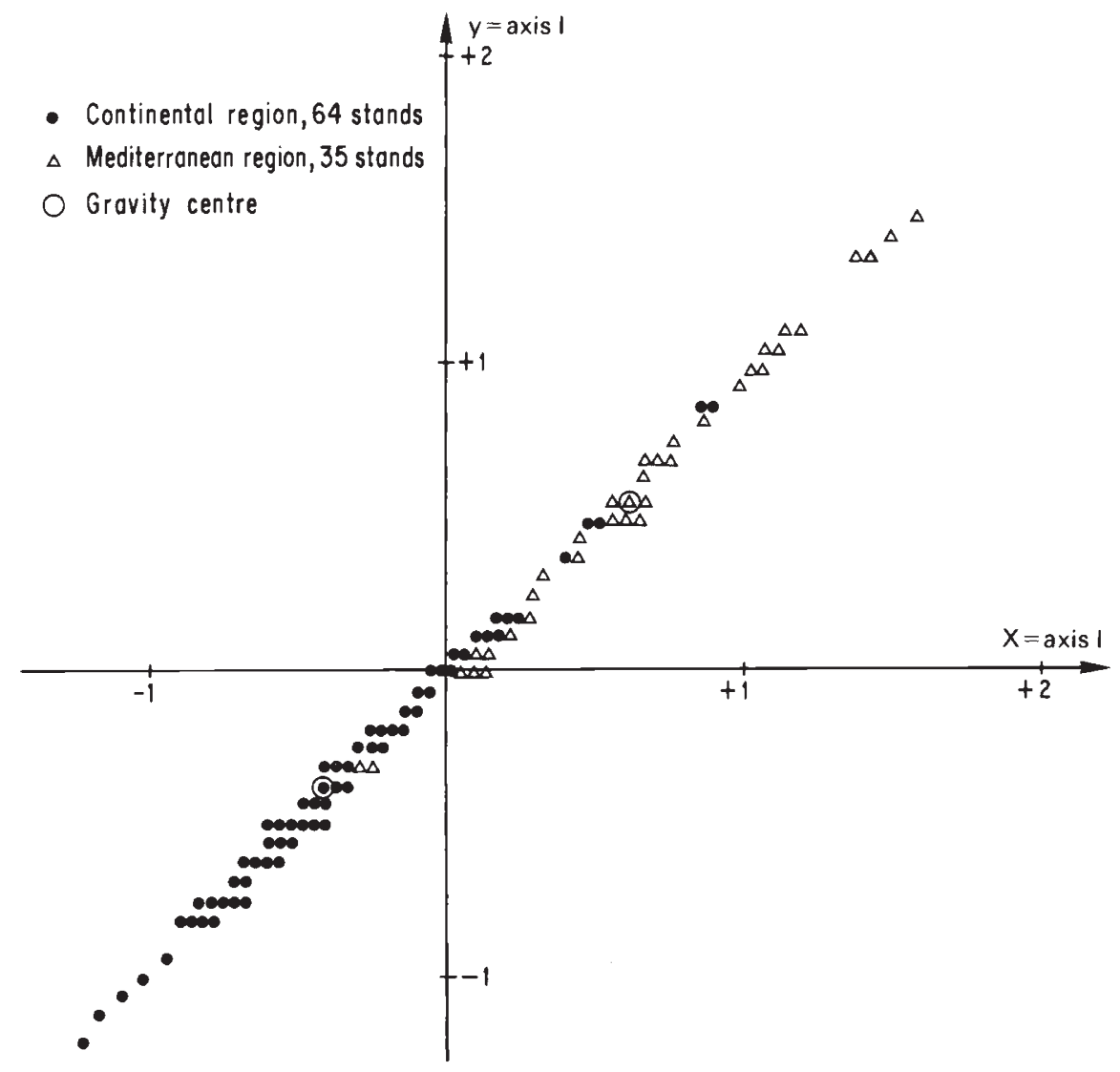

Figure 2 Discriminant analysis including $P X-1, P X-2, G O T-1, M D H-1$ and $I D H-1$ loci: comparison between climatic regions. Variance axis I: 100 per cent. Variable discriminant values for $I D H-1-84:+0 \cdot 315, I D H-1-100:+0 \cdot 086, P X-2-13$ : $-0 \cdot 070$, IDH-1-116; +0.063, GOT-1-100 and -105: $-0.030, P X-1-100$ and $-105:-0.021, M D H-1-100$ and $-120:+0.015, P X-2-39$ : $-0.007, P X-2-26:-0.002$.

locus; also we found $0.05<P<0.10$ for the two most frequent alleles of $I D H-1$ (table 2). The discriminant analysis including all loci except $P G I-1$ (fig. 2) shows a difference between the two climatic regions, however their discrimination is not quite complete. $I D H-1$ locus is the most responsible for this discrimination.

\section{Comparisons between countries}

Results differ according to the locus considered:

$P X-1$. The allelic frequencies and the gene diversities vary according to the variety of climates (tables 2 and 3). Diversity is significantly lower in Poland than in all other countries (table 3 ). It increases in Czechoslovakia and reaches its highest values in the central part of the studied area (Croatia, Serbia, Bulgaria, Rumania). Then it decreases towards the South, particularly in Corsica where it becomes significantly different from all other values.

$P X-2$. The gene diversity variations may be rather well related to the altitudinal range of the beechwoods: Croatia, $1385 \mathrm{~m}\left(H_{\mathrm{T}}=0.431\right.$ and 0.428$)$; Czechoslovakia, $1060 \mathrm{~m}\left(H_{\mathrm{T}}=0.404\right)$; Italy, $650 \mathrm{~m}$ $\left(H_{\mathrm{T}}=0.365\right)$; Serbia, Rumania and Bulgaria, $600 \mathrm{~m}\left(H_{\mathrm{T}}=0.317\right)$; Poland, $400 \mathrm{~m}\left(H_{\mathrm{T}}=0.333\right)$; Corsica, $350 \mathrm{~m}\left(H_{\mathrm{T}}=0 \cdot 265\right)$.

GOT-1 and $I D H-1$. The gene diversity reveals a latitudinal opposition between the northern and the southern parts of the studied area (table 3); however, Mediterranean Croatia does not generally differ from the continental countries. These two locus diversities vary in an opposite way: GOT-1 diversity increases from the north to the south whereas $I D H-1$ one decreases. 
Table 2 Mean allelic frequencies according to regions and countries

\begin{tabular}{|c|c|c|c|c|c|c|c|c|c|c|c|c|}
\hline \multirow{2}{*}{$\begin{array}{l}\text { Loci and } \\
\text { alleles }\end{array}$} & \multirow{2}{*}{$\begin{array}{l}\text { Whole } \\
\text { area }\end{array}$} & \multicolumn{2}{|c|}{ Regions } & \multirow{2}{*}{$\begin{array}{l}\text { Countries } \\
\text { intra-regions } \\
\text { (1) }\end{array}$} & & \multicolumn{7}{|c|}{ Countries } \\
\hline & & Cont. & Medit. & & & PL & $\mathrm{CS}$ & BRS & $\mathrm{CrC}$ & $\mathrm{CrM}$ & I & $\mathrm{Co}$ \\
\hline \multirow[t]{3}{*}{$P X-1-100$} & 0.65 & 0.66 & 0.60 & & & 0.88 & 0.65 & 0.61 & 0.64 & 0.50 & 0.64 & 0.79 \\
\hline & & \multirow{2}{*}{\multicolumn{2}{|c|}{$P>0 \cdot 10$}} & & (2) & $\mathrm{b}$ & & $\mathrm{a}$ & & & $\mathrm{a}$ & $\mathrm{b}$ \\
\hline & & & & $* * *$ & (3) & $\mathrm{c}$ & b & $a b$ & b & $\mathrm{a}$ & $a b$ & $\mathrm{~d}$ \\
\hline \multirow[t]{3}{*}{$P X-2-39$} & $0 \cdot 20$ & $0 \cdot 19$ & 0.22 & & & $0 \cdot 18$ & 0.20 & $0 \cdot 15$ & $0 \cdot 24$ & $0 \cdot 23$ & $0 \cdot 20$ & $0 \cdot 15$ \\
\hline & & \multirow{2}{*}{\multicolumn{2}{|c|}{$P>0 \cdot 10$}} & & $(2)$ & $\mathrm{ab}$ & $\mathrm{ab}$ & $\mathbf{a}$ & b & b & $\mathrm{ab}$ & $\mathrm{ab}$ \\
\hline & & & & $* * *$ & (3) & $a b c$ & $\mathrm{bc}$ & $\mathrm{a}$ & d & $\mathrm{cd}$ & bd & $\mathrm{ab}$ \\
\hline \multirow[t]{3}{*}{$P X-2-26$} & $0 \cdot 76$ & 0.76 & $0 \cdot 74$ & & & $0 \cdot 80$ & 0.74 & $0 \cdot 80$ & $0 \cdot 71$ & $0 \cdot 73$ & $0 \cdot 77$ & $0 \cdot 84$ \\
\hline & & \multirow{2}{*}{\multicolumn{2}{|c|}{$P>0 \cdot 10$}} & & $(2)$ & $\mathrm{ac}$ & $\mathrm{ac}$ & bc & $\mathrm{a}$ & $\mathrm{ab}$ & $\mathrm{ac}$ & c \\
\hline & & & & $* * *$ & (3) & $\mathrm{bc}$ & $a b$ & $\mathrm{c}$ & $\mathrm{a}$ & $\mathrm{a}$ & $a b c$ & $\mathrm{c}$ \\
\hline \multirow[t]{3}{*}{$G O T-1-100$} & $0 \cdot 90$ & 0.92 & 0.87 & & & 0.94 & 0.93 & 0.87 & 0.95 & 0.93 & $0 \cdot 83$ & 0.76 \\
\hline & & \multirow{2}{*}{\multicolumn{2}{|c|}{$0.05<P<0.10$}} & & $(2)$ & c & c & $\mathrm{b}$ & $\mathrm{c}$ & c & $a b$ & a \\
\hline & & & & $* * *$ & (3) & $\mathrm{c}$ & $\mathrm{c}$ & $\mathrm{b}$ & $\mathrm{c}$ & c & $\mathrm{a}$ & a \\
\hline \multirow[t]{3}{*}{$M D H-1-100$} & 0.77 & $0 \cdot 75$ & $0 \cdot 80$ & & & $0 \cdot 72$ & 0.75 & $0 \cdot 78$ & $0 \cdot 74$ & $0 \cdot 80$ & 0.86 & 0.79 \\
\hline & & \multirow{2}{*}{\multicolumn{2}{|c|}{$*$}} & & $(2)$ & $\mathbf{a}$ & $\mathrm{a}$ & $\mathbf{a}$ & $\mathrm{a}$ & $\mathbf{a}$ & $\mathrm{b}$ & a \\
\hline & & & & $* *$ & (3) & $\mathrm{a}$ & $\mathrm{ab}$ & $\mathrm{bc}$ & $\mathrm{abc}$ & $\mathrm{c}$ & $\mathrm{d}$ & $\mathrm{abc}$ \\
\hline \multirow[t]{3}{*}{$I D H-1-116$} & $0 \cdot 31$ & $0 \cdot 35$ & $0 \cdot 27$ & & & 0.34 & $0 \cdot 34$ & 0.43 & $0 \cdot 33$ & $0 \cdot 31$ & 0.24 & $0 \cdot 18$ \\
\hline & & \multirow{2}{*}{\multicolumn{2}{|c|}{$0.05<P<0.10$}} & & $(2)$ & bc & $\mathrm{bc}$ & c & bc & bc & $a b$ & a \\
\hline & & & & $* *$ & (3) & $\mathrm{cd}$ & $\mathrm{c}$ & $\mathrm{d}$ & bcd & c & $\mathrm{b}$ & a \\
\hline \multirow[t]{2}{*}{$I D H-1-100$} & 0.68 & 0.65 & $0 \cdot 72$ & & & $0 \cdot 66$ & 0.66 & 0.57 & 0.67 & $0 \cdot 68$ & 0.75 & $0 \cdot 81$ \\
\hline & & \multicolumn{2}{|c|}{$0.05<P<0.10$} & $* *$ & $\begin{array}{l}(2) \\
(3)\end{array}$ & $\begin{array}{l}a b \\
b\end{array}$ & $\begin{array}{l}a b \\
b\end{array}$ & $\begin{array}{l}\mathrm{a} \\
\mathrm{a}\end{array}$ & $\begin{array}{l}\mathrm{ab} \\
\mathrm{abc}\end{array}$ & $\begin{array}{l}a b \\
b\end{array}$ & $\begin{array}{l}\mathrm{bc} \\
\mathrm{c}\end{array}$ & $\begin{array}{l}c \\
d\end{array}$ \\
\hline \multirow[t]{3}{*}{$P G I-1-100$} & 0.98 & 0.98 & 0.98 & & & - & 0.99 & 0.97 & 0.98 & 0.96 & 0.99 & 0.96 \\
\hline & & \multirow{2}{*}{\multicolumn{2}{|c|}{$P>0 \cdot 10$}} & & (2) & - & a & $\mathrm{a}$ & $\mathbf{a}$ & $\mathrm{a}$ & $\mathbf{a}$ & a \\
\hline & & & & $*$ & (3) & - & $\mathbf{a}$ & $\mathbf{a}$ & $\mathbf{a}$ & a & $\mathrm{a}$ & $\mathrm{a}$ \\
\hline \multirow[t]{3}{*}{$P G I-1-87$} & 0.02 & 0.02 & 0.02 & & & - & $0 \cdot 01$ & 0.02 & 0.02 & 0.04 & 0.01 & $0 \cdot 04$ \\
\hline & & \multirow{2}{*}{\multicolumn{2}{|c|}{$P>0.10$}} & & (2) & - & $\mathrm{a}$ & $\mathrm{a}$ & a & a & a & a \\
\hline & & & & $*$ & (3) & - & $\mathrm{a}$ & $\mathrm{a}$ & $\mathbf{a}$ & $\mathrm{b}$ & $\mathrm{a}$ & b \\
\hline
\end{tabular}

(1) Nested Anova (Sokal and Rohlf 1981).

(2) Multiple comparisons among pairs of means based on unequal sample sizes: Tukey-Kramer's test (Dunnett 1980).

(3) Single classification Anova.

* $P<0.05$.

** $P<0.01$.

$* * * P<0.001$.

Any two countries not characterized by the same letter present allelic frequencies significantly different one from the other. PL, Poland; CS, Czechoslovakia; BRS, Bulgaria + Rumania + Serbia; CrC, continental Croatia; CrM, Mediterranean Croatia; I, Italy; Co, Corsica.

$M D H-1$. The gene diversity and partly allelic frequencies vary also as a function of latitude, in almost the same way as $I D H-1$ ones, however Mediterranean and continental Croatia differ from one another.

$P G I$-1. Polymorphism and variations of allelic frequencies are very low. Only Italy seems to be apart from the other countries.

The discriminant analysis including $P X-1, P X$ 2, GOT-1, IDH-1 and $M D H-1$ nearly reveals the difference between four latitudinal groups of beechwoods for which discrimination is not complete (fig. 3): two southern groups (1) in Italy and (2) in Corsica, one intermediate group (3) in Bulgeria, Serbia, Rumania, continental and Mediterranean Croatia and Czechoslovakia, (4) one last group in Poland. It also shows that the two climatic regions of Croatia (continental and Mediterranean) are not different. As the two axes I and II only explain about 70 per cent of the variance, another analysis was carried out on axes I and III 
Table 3 Mean gene diversity according to regions and countries-Mann-Whitney test

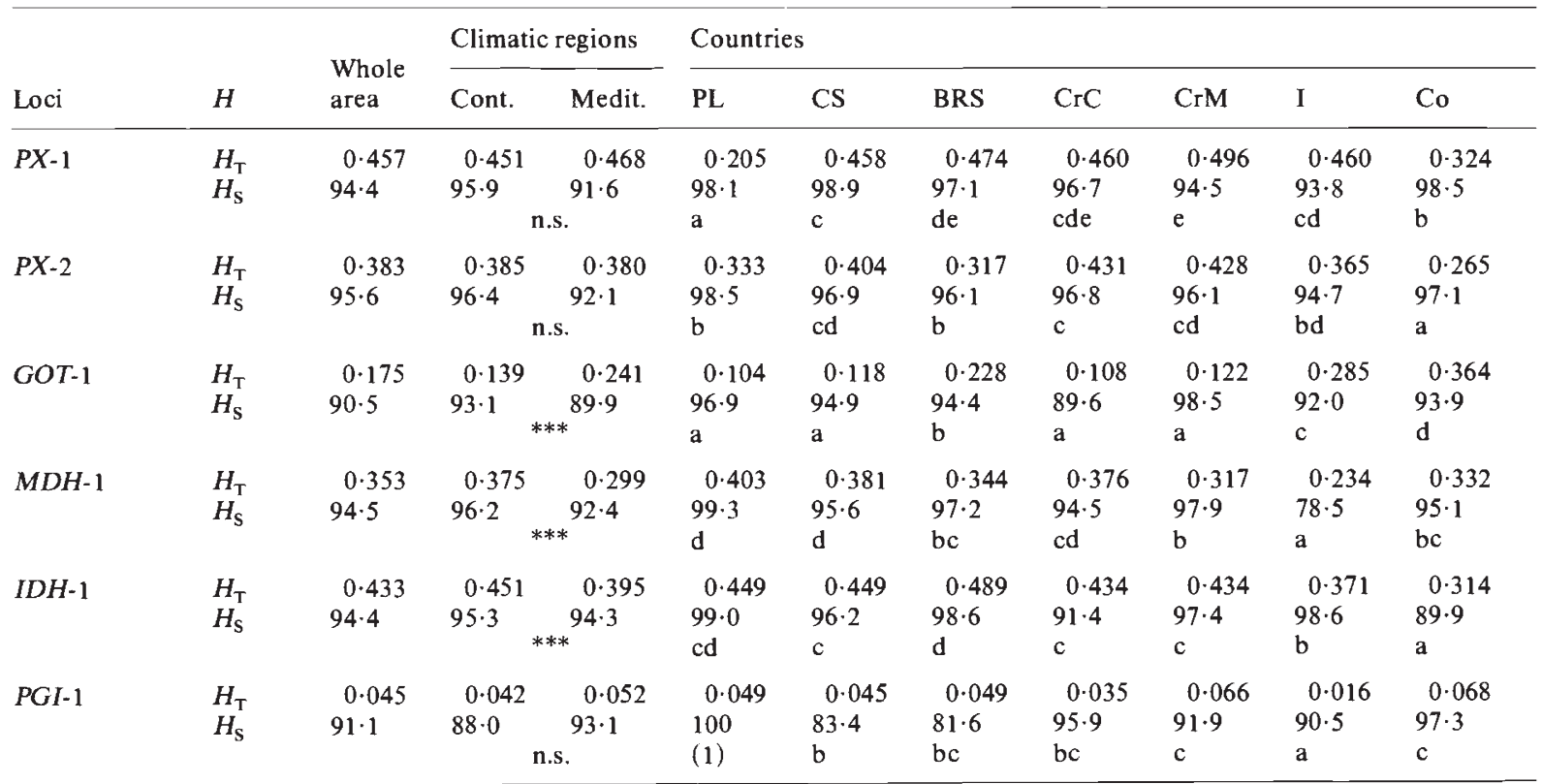

$H_{\mathrm{T}}$, total gene diversity; $H_{\mathrm{S}}$, intra-component of the diversity (\%). Cont., Continental region; Medit., Mediterranean region. PL, Poland; CS, Czechoslovakia; BRS, Bulgaria + Rumania + Serbia; CrC, continental Croatia; CrM Mediterranean Croatia; I, Italy; Co, Corsica. ns $=$ not significant.

*** $P<0.001$.

Any two countries not characterized by the same letter present gene diversities significantly different one from the other. (1) No comparison including Poland was performed because of the small number of studied populations.

(the axis III explains $20 \cdot 72$ per cent of the variance): it completely confirms the discrimination between the two southern groups of beech populations (in Italy and in Corsica) and all the others.

\section{Genotypic differentiation}

Multilocus estimates of $F$-statistics required balanced data in all loci. Therefore, the PGI-1 locus was not taken into account because of the low number of Polish beech stands examined for this locus. In addition, the procedure for the $I D H-1$ locus has recently been improved, so it was not possible to analyse it for all the sampled stands. $F$-statistic estimations were therefore carried out on those 99 beechwoods for which results at all loci are complete.

All mutilocus estimates differ from $0(P<0.05)$ over the whole area as well as in continental and Mediterranean regions and in most countries (table 4). All $F_{\text {IS }}$ values are positive; also they are higher than $F_{\mathrm{ST}}$ values except in Czechoslovakia and Corsica. As for diversities, the intrapopulation component of the genetic differentiation is higher than the inter-one.

The number of beech stands and trees we studied varies from one country to another; thus, it is better to only compare the genotypic differentiation ( $F_{\mathrm{IS}}, F_{\mathrm{ST}}$ and $F_{\mathrm{IT}}$ ) of countries having similar sample sizes. In countries with lower stand numbers, intra- and interpopulation differentiation tends to be lower towards the north in Poland than towards the south in Italy (table 4). Beechwoods located in an intermediate area (Bulgaria, Rumania, Serbia) also show an intermediate genotypic differentiation. F-estimates do not differ from 0 in Corsica, an island located in the Mediterranean region. In countries with larger stand number, the intrapopulation differentiation is significantly lower in Czechoslovakia than in Croatia. In Croatia, comparisons between continental and Mediterranean regions do not reveal any significant differences. Thus, genotypic differentiation within populations seems to be similar in stands belonging to the same country and located near to each other even if they grow under different 


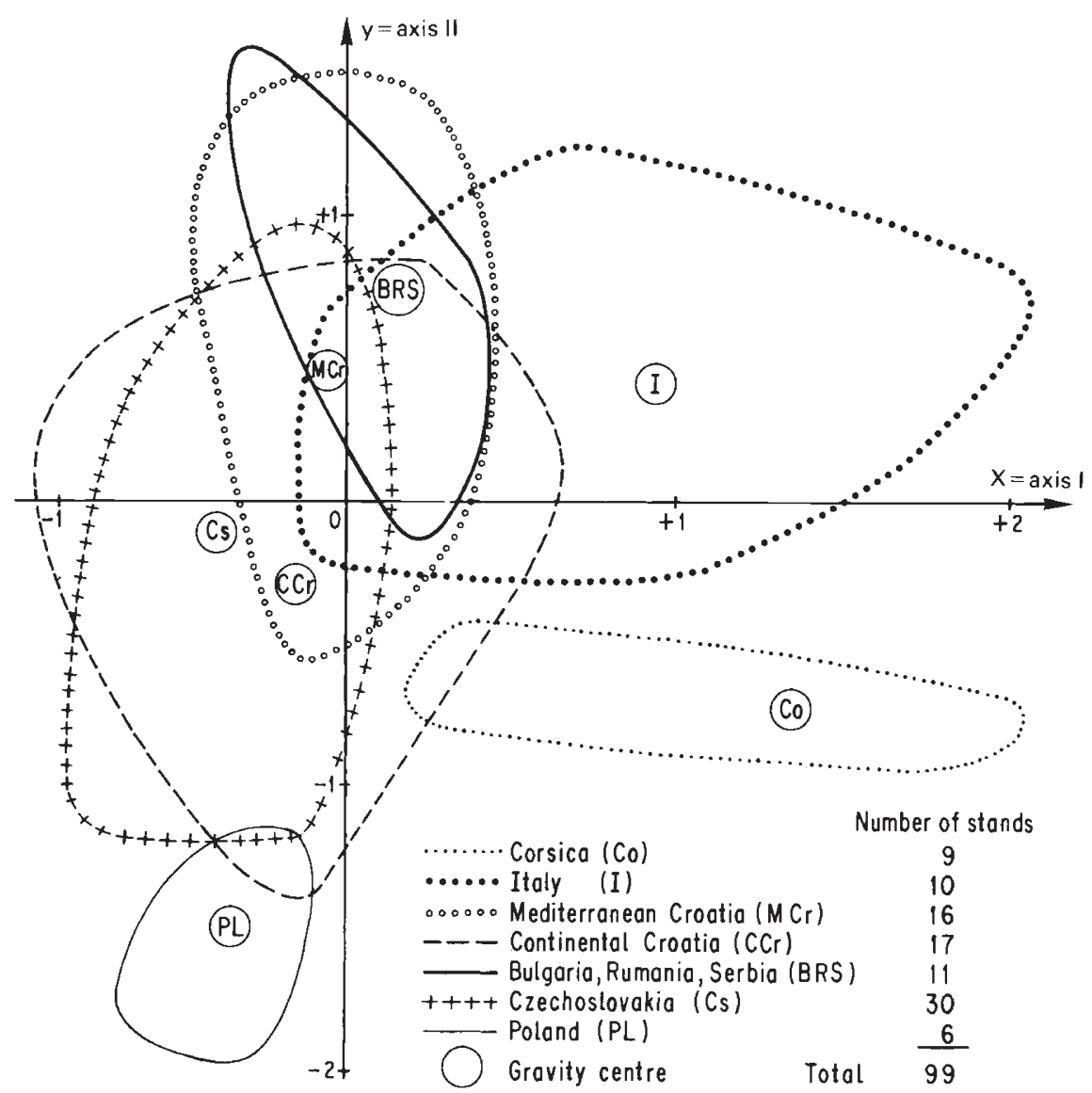

Figure 3 Discriminant analysis including $P X-1, P X-2, G O T-1, M D H-1$ and $I D H-1$ loci: comparison between countries. Variance axis I: $39 \cdot 15$ per cent, axis II: $30 \cdot 51$ per cent. Variable discriminant values (I+II) for $G O T-1-100$ and $-105:-0 \cdot 089, P X-1-100$ and -105: $-0.058, I D H-1-84:+0.037, M D H-1-100$ and $-120:+0.028, P X-2-13:-0.026, P X-2-39:-0.022, I D H-1-116$ : $-0.020, I D H-1-100:-0.017, P X-2-26:-0 \cdot 012$.

Table 4 Multilocus $F$-statistic values according to regions and countries $(P X-1, P X-2, G O T-1, M D H-1$ and IDH-1. Weir and Cockerham 1984)

\begin{tabular}{llll}
$\begin{array}{l}\text { Regions, countries } \\
\text { and stand numbers }\end{array}$ & $F_{\text {is }}$ & $F_{\text {st }}$ & $F_{\text {it }}$ \\
\hline Whole area (99) & $+0.065(0.030)$ & $+0.054(0.000)$ & $+0 \cdot 115(0.026)$ \\
Continental region (64) & $+0.053(0.026)$ & $+0.038(0.010)$ & $+0.089(0.026)$ \\
Mediterranean region (35) & $+0.085(0.034)$ & $+0.071(0.020)$ & $+0.150(0.036)$ \\
Poland (6) & $+0.043(0.017)$ & $+0.003(0.000)$ & $+0.046(0.017)$ \\
Czechoslovakia (30) & $+0.013(0.024)$ & $+0.033(0.010)$ & $+0.046(0.020)$ \\
B+R+S (11) & $+0.095(0.054)$ & $+0.026(0.014)$ & $+0.119(0.056)$ \\
Croatia (33) & $+0.088(0.026)$ & $+0.046(0.010)$ & $+0.131(0.020)$ \\
$\quad$ Continental stands (17) & $+0.094(0.026)$ & $+0.037(0.014)$ & $+0.128(0.014)$ \\
Italy (10) & $+0.083(0.031)$ & $+0.054(0.022)$ & $+0.133(0.030)$ \\
Corsica (9) & $+0.125(0.047)$ & $+0.058(0.030)$ & $+0.176(0.053)$ \\
\hline
\end{tabular}
Standard errors appear in parentheses and were derived by jackknifing over stands $-\mathrm{B}+\mathrm{R}+\mathrm{S}$ : Bulgaria+
Rumania+Serbia. 
climatic conditions whereas this differentiation can differ between two countries within one climatic region.

\section{DISCUSSION AND CONCLUSION}

The arguments put forward in the introduction concerning the origins of the beech populations suggest that there has been more opportunity for the development of genetic differentiation within and among populations in the south than in the north of the range.

\section{Allelic level}

In the whole area, some loci $(P X-1, P X-2, M D H-1$ and $I D H-1)$ are very polymorphic; GOT-1 locus is less polymorphic and PGI-1 locus is nearly monomorphic.

Allelic variations of $P X-1$ and $P X-2$ loci were shown to be partially related to climatic changes. For $P X-2$, they are related to the altitudinal range of the beech stands. For $P X-1$, the gene diversity is lowest within countries where all beechwoods grow under optimal climatic conditions; it is highest in Croatia where both optimal and extreme climates for the Beech can be found. In some of our previous works about other southern countries far apart from each other, we also found variations of $P X-2$ allelic diversity according to the altitudinal range of the stands (Thiébaut et al., 1982; Thiébaut, 1984; Barrière et al., 1985; Cuguen et al., 1985; Comps et al., 1987; Comps et al., 1989). For PX-1, we showed a positive correlation between the climatic conditions extreme for the Beech (at high and low altitudes) and the highest values of $P X-1$ 105 frequency. These previous results suggested the possibility of a selection effect as we always observed the same allelic variations in connection with the same climatic changes, as for other species (Clarke, 1975; Bergmann, 1978). In another study (yet unpublished), we found a significant correlation between the highest frequencies of $P X-1-105$ allele and the driest stands of the Mediterranean slope of the Dinaric Alps in Croatia. The discrimant analysis based on all loci confirms the significant differences between continental and Mediterranean regions.

Among countries, the discriminant analysis displays four pools of beechwoods for which discrimination is rather good but not complete: (1) in Poland, (2) in Czechoslovakia, Bulgaria +
Rumania + Serbia, Croatia, (3) in Italy and (4) in Corsica.

Considering other studies on genetic differentiation of anemophilous forest tree species, the interpopulation component of the diversity is generally found lower than the intrapopulation one and varies between 0 and 15 per cent (see review in Gullberg et al., 1985). In this study, it varies from 4.2 to $9 \cdot 5$ per cent over the whole area and it is lower than the intrapopulation component both in continental and Mediterranean regions. Nevertheless, it is the highest in the Mediterranean region for all loci except PGI-1. This suggests the following remarks:

(1) Almost all results are rather similar in spite of different calculation methods, population size and locus number. This homogeneity expresses a similar behaviour of allogamic and anemophilous forest tree species (conifers as well as deciduous species like the Beech) for which the intracomponent of the diversity is clearly higher than the inter-component because of important gene flows from one population to another.

(2) Differences between studied species in Eurasia as well as in America suggested to Gullberg et al. (1985) that populations that have settled within areas covered by ice during the glacial periods in the north have lower inter-population components of the diversity than those located in the south. One obvious explanation for lower differentiation in northern populations could be that the time that has passed after the last glaciation has been too short.

The results can be related to the hypothesis assumed for the Beech regarding the higher age of southern populations and it is known that these populations had been spread out from several secondary sources isolated from each other during glaciations. In addition, the three studied Mediterranean countries are rather separate from one another and more or less from other countries of central Europe: Corsica is entirely isolated by the sea, also Italy by the sea along most of the country and by mountains in the north; Mediterranean Croatia is separated from Italy by the Adriatic sea but much less from the continental Croatian slope of the Dinaric Alps. This may have reduced the postglacial exchanges between the three Mediterranean countries but not migrations from Mediterranean Croatia towards central Europe; so, it can explain the observed discriminations. The degree of isolation and postglacial migrations must be taken into account in Europe because they can also play an important role in the genetic differentiation of beech populations. 


\section{Genotypic level}

Mostly multilocus estimates of $F$-statistics differ significantly from zero. $F_{\mathrm{IS}}$ values are always positive and generally higher than $F_{\mathrm{ST}}$ ones. These results imply:

(1) The existence of a total genotypic differentiation with intra- and interpopulation components. In comparison with the previous study of Cuguen et al. (1988), including 250 beech populations from Europe and using three loci, we have obtained similar results concerning $F_{\mathrm{ST}}$. Multilocus estimate of $F_{\mathrm{IS}}$ is lower than that obtained by Cuguen et al. (1988) ( $F_{\mathrm{IS}}=0.065$ and $0 \cdot 120$, respectively); this may be due to the two new loci ( $I D H-1$ and $M D H-1$ ) being used in our study which possess similar variations but with a contradictory trend. In most studied species, values of $F_{\mathrm{ST}}$ tend indeed to be lower than 0.100 and provide evidence that genotypic heterogeneity is generally rather low. The Beech shows the highest estimates among the anemophilous forest tree species, with only two exceptions: Pinus banksiana and Pinus halepensis which reach values about $0 \cdot 120$ (Grunwald et al., 1986; Dancik and Yeh, 1983; O'Reilly et al., 1985; Plessas and Strauss, 1986). Higher values of $F_{\mathrm{ST}}$ could be due to the larger area and higher number of investigated stands but, however, any generalization is not possible regarding the lower number of loci.

(2) A general tendency towards a heterozygote deficit. As pointed out by Brown (1979), allogamic species often exhibit a heterozygote deficit. Among the different causes he listed, two can be applied to the Beech, selfing and isolation by distance: (a) referring to the low level of self-fertilization rate of the Beech (from 0 to 0.05 , Merzeau et al. in preparation), self-fertilization can explain only a small part of the observed heterozygote deficit. (b) Cuguen et al. (1986) formulated the "isolation by distance" hypothesis as the most important cause of heterozygote deficit in Beech.

According to our previous hypothesis, the genotypic differentiation within and among populations tends to be higher towards the south. The differences between continental and Mediterranean regions are, however, not significant. This may be due to the applied method (jackknife procedure) or the lower number of investigated populations in some countries with higher ecological differentiation (e.g., Rumania, Bulgaria, Serbia, Poland).

Finally, three causes, selection, gene flows and the mating system have been proposed to explain the genetic differentiation of beech populations.
But, it is rather difficult to rank them according to their significance.

\section{REFERENCES}

BARRIĖRE, G., COMPS, B., CUGUEN, J., N'TSIBA, F. AND THIÉBAUT, B. 1985. The genetic ecological variability of Beech (Fagus sylvatica L.) in Europe, an alloenzymatic study: genetic isolations of beechwoods. IUFROBuchensymposium, H. J. Muhs (ed.), Hamburg. Mitteilungen der Bundesforschungsanstalt für Forst- und Hol zwirtschaft, 150, 24-50.

BERGMANN, F. 1978. The allelic distribution at an acid phosphatase locus in Norway spruce (Picea abies) along similar climatic gradients Theor. Appl. Genet., 32, 57-64.

BEUG, H. J. 1967. On the forest history of the Dalmatian coast. Rev. Paléobot. Palynol., 2, 271-279.

BROWN, A. H. D. 1979. Enzyme polymorphism in plant populations. Theor. Pop. Biol. 15, 1-42.

CLARKE, B. 1975. The contribution of ecological genetics to evolutionary theory: detecting the direct effects of natural selection on particular polymorphic loci. Genetics, 79, 101113.

COMPS, B. 1972. Essai sur le Déterminisme écologique du Hêtre (Fagus sylvatica L.) en Aquitaine. Thèse de Doctorat d'Etat, Université de Bordeaux I.

COMPS, B., BARRIÈRE, G., MERZEAU, D. AND LETOUZEY, J. 1987. La variabilité alloenzymatique des hêtraies dans les sous-domaines médio- et eu-atlantiques d'Europe. Can. J. For. Res. 17, 1043-1049.

COMPS, B., PAUle, L., SUGAR, I., THIÉBAUT, B. AND TRINAJSTIC, I. 1989. Genetic variability in beechwoods (Fagus sylvatica L.) over central Europe, allozymic variations in six enzyme systems: spatial differentiation among and within populations. In Korbel, B. and Paule, L. (eds) IUFRO-Buchensymposium, Zvolen. In press.

CUGUEN, J. 1986. Différenciation génétique inter-et intrapopulation d' un Arbre forestier anémophile: le Cas du Hêtre (Fagus sylvatica $L$.). Thèse de Doctorat, Université des Sciences et Techniques du Languedoc, Montpellier II.

CUGUEN, J., THIÉBAUT, B., N'TSIBA, F. AND BARRIÈRE, G. 1985. Enzymatic variability of beech stands ( Fagus sylvatica L.) on three scales in Europe: evolutionary mechanisms. In (eds) Jacquart, P., Heim, G. and Antonovics, J. Genetic Differentiation and Dispersal in Plants, NATO Series, vol, 1, G5, pp. 17-39.

CUGUeN, J., MERZEAU, D. AND THIÉBAUT, B. 1988. Genetic structure of the European beech stands (Fagus sylvatica L.): F-statistics and importance of the mating system characteristics in their evolution. Heredity, 60, 91-100.

DANCIK, B. P. AND YEH, F. C. 1983. Allozyme variability and evolution of lodgepole pine (Pinus contorta var. latifolia) and Jack pine (P. banksiana) in Alberta. Can. J. Genet. Cytol, $15,57-64$.

DUNNET, C. W. 1980. Pairwise multiple comparisons in the homogeneous variance, unequal sample size case. J. amer. Stat. Assoc., 75, 789-795.

ESCOUFFIER, Y., DELCAMP, A. AND JUNCA HOLMES, S. 1988. L.E.A.S., logiciel d'enseignement et d'analyses statistiques. Unité de Biométrie, Université des Sciences et Techniques du Languedoc et Institut National de la Recherche Agronomique, Montpellier, France. 
FELBER, F. AND THIÉBAUT, B. 1982. La hêtraie méridionale française: structure génétique en relation avec les conditions écologiques. Ber. des 25. intern. Symp. der intern. Vereinig. für Vegetationskunde, Rinteln, A. R. Gartner Verlag, Vaduz, pp. 459-473.

FELBER F. AND THIÉBAUT, B. 1984. Etude préliminaire sur le polymorphisme enzymatique du Hêtre (Fagus sylvatica $L$.), variabilté génétique de deux systèmes de peroxydases en relation avec les conditions écologiques. Oecol. Plant., 5 , 133-150.

GREGORIUS, H. R., KRAUHAUSSEN, J. AND MULLER-STARCK, G. 1986. Spatial and temporal differentiation among the seed in a stand of Fagus sylvatica L. Heredity, 56, 255-262.

GRÜNWALD, C., SCHILlER, G. AND CONKLE, M. T. 1986. Stands and plantations of Aleppo pine in Israël. Israël $J$. Bot., 35, 161-174.

GULLBERG, U., YAZDANI, R., RUDIN, D. AND RYMAN, N. 1985. Allozyme variation in Scots pine (Pinus sylvestris $L$.) in Sweden. Silvae Genetica, 34, 193-201.

JALUT, M. 1974. Evolution de la Végétation et Variations climatiques durant les quinze derniers Millénaires dans l'extrémité orientale des Pyrénées. Thèse de Doctorat d'Etat, Université de Toulouse.

JALUT, M., SACCHI, D. AND VERNET, J. L. 1975. Mise en évidence d'un refuge tardiglaciaire à moyenne altitude sur le versant nord-oriental des Pyrénées (Belirs, alt. $960 \mathrm{~m}$, Aude). C. R. hebd. Acad. Sci. Paris, série D, 280, 1781-1784.

KIM, Z. S. 1979. Inheritance of leucine aminopeptidase and acid phosphatase iosenzymes in Beech (Fagus sylvatica L.). Silvae Genetica, 28, 68-71.

KIM, Z. S. 1980. Veränderung der genetischen Struktur von Buchenpopulationen durch Viabilitätsselektion im Keimlingstadium. Forstwiss. Diss. Universität Göttingen, 96 p.

MERZEAU, D., DI GIUSTO, F., COMPS, B., THIÉBAUT, B., LETOUZEY, J. AND GUCUEN, J. 1989. Genetic control of isozyme systems and heterogeneity of pollen contribution in Beech (Fagus sylvatica L.). Silvae Genetica. In press.

MISIC, v. 1957. The Variability and Ecology of the Beech in Yugoslavia. Srpska Akademija Nanka Institut za Ekologiju i Biogeografija, $181 \mathrm{pp}$.

MÜLLER-STARCK, G. 1985. Geneic differences between "tolerant" and "sensitive" beeches (Fagus sylvatica L.) in an environmentally stressed adult forest stand. Silvae Genetica, 34, 241-247.

NEI, M. 1973. Analysis of gene diversity in subdivided populations. Proc. Natl Acad. Sci. USA, 70, 3321-3323.

NEI, M. 1977. Statistics and analysis of gene diversity in subdivided populations. Ann. hum. Genet. 41, 225-233.

NIELSEN, P. C. AND SCHAFFALITZKY DE MUCKADELL, M. 1954. Flower observations and controlled pollinations in Fagus. Z. Forstgenet., 3, 6-17.

NOETHER, G. E. 1976. Introduction to Statistics. A Non-parametric Approach. Houghton Mifflin Cy, Boston, second edition.

N'TSIBA, F. 1984. Etude de la Variabilité génétique du Hêtre (Fagus sylvatica L.): Polymorphisme Enzymatique des Hêtraies dans les Alpes méridionales à des Échelles d'observation différentes. Thèse de 3ème cycle, Université de Nancy $I$.

OLDFIELD, F. 1960. Three pollen analyses from an interglacial mudbed on the foreshore near Biarritz, South-West France. Bull. Cent. Etude Rech. Sci. Biarritz, 3, 53-62.
O'REILly, G. J., PARKeR, W. H. AND CHELIAK, W. M. 1985. Isozyme differentiation of upland and lowland Picea mariana stands in Northern Ontario. Silvae Genetica, 34, 214-221.

PAQUeREAU, M. M. 1965. Les refuges végétaux d'après les analyses poliniques dans le Sud-Ouest de la France. Actes Soc. Linn. Bordeaux série B, 102, 1-7.

PAQUEREAU, M. M. 1970. Flores et climats paléolithiques dans le Sud Ouest de la France. Rev. Géogr. Phys. Géol. Dyn. 12, 109-116.

PAQUeREAU, M. M. 1974. Le Würm ancien en Périord. Quaternaria, $18,67-115$ et $117-159$.

PLESSAS, M. E. AND STRAUSS, S. H. 1986. Allozyme differentiation among populations, stands and cohorts in Monterey pine. Can. J. For. Res. 16, 1155-1164.

PONS, A. 1983. La paléoécologie face aux variations spatiales du bioclimat méditerranéen. Colloque "Bioclimatologie méditerranéenne”, Fondation L. Emberger et C. Sauvage, Montpellier, II, 3: 1-9.

SCHAFFALITZKY DE MUCKADELL, M. 1955. A development stage in Fagus sylvatica L. characterized by abundant flowering. Physiol. Pl. 8, 370-373.

SERCELJ, A. 1970. Das refugial Problem der spätglaziale Vegetations entwicklung im Norfeld des sudost-Alpenraumes. Mitteil. Ostalp. Wpflanzensoziol. Arbeitsgem. 10, 76-78.

SOKAL, R. R. AND ROHLF, F. J. 1981. Biometry. W. H. Freeman and $\mathrm{Cy}$, New York, second edition.

THIÉBAUT, B. 1984. Variabilité génétique de "hêtre commun" (Fagus sylvatica fi.) dans les milieux montagnards et de hautes altitudes en Europe. Colloque Ecologie et Biogéographie des milieux montagnards et de haute altitude, Gabas, France et Documents d'Ecologie pyrénéenne, 3-4, 513-521.

THIÉBAUT, B., LUMARET, R. AND VERnET, PH. 1982. The bud enzymes of beech (Fagus sylvatica L.). Genetic distinction and analysis of polymorphism in several french populations. Silvae Genetica, 31, 51-60.

THIÉBAUT, B., CUGUEN, J., COMPS, B. AND MERZEAU, D. 1986. Influence du mode de reproduction sur la structure génétique des populations d'arbres anémophiles: le cas du Hêtre (Fagus sylvatica L.). Colloque Natl C.N.R.S. Biologie des Populations, Lyon, pp. 518-527.

TRIAT-LAVAL, H. 1978. Contribution pollenanalytique à l' Histoire tard iet post-glaciaire de la Végétation de la basse Vallée du Rhone. Thèse de Doctorat d'Etat, Université d'AixMarseille III.

VERNET, J. L. 1981. Histoire et répartition, l'histoire du Hêtre. In Teissier du Cros, E. (ed.) Le Hêtre, I.N.R.A., Départment de recherches forestières, France, pp. 49-58.

WEIR, B. S. AND COCKERHAM, C. C. 1984. Estimating F-statistics for the analysis of population structure. Evolution, 38 , 1358-1370.

WRIGHT, S. 1943. Isolation by distance. Genetics, 28, 114-138. WRIGHT, S. 1946. Isolation by distance under diverse systems of mating. Genetics 31, 39-59.

Wright, S. 1951. The genetical structure of populations. Ann. Eugenics, 15, 323-354.

WRIGHT, S. 1965. The interpretation of population structure by F-statistics with special regard to systems of mating. Evolution, 19, 395-420.

WrIGHT, S. 1978. Evolution and the Genetics of Populations. Vol. 4. Variability within and among Natural Populations. University of Chicago Press, Chicago. 